\title{
Causality Relationship between Spot and Futures Bitcoin Prices in CME
}

\section{Letife ÖZDEMİR ${ }^{\mathrm{a}}$}

${ }^{\text {a }}$ Faculty of Economics and Administrative Sciences, University of Afyon Kocatepe, Afyonkarahisar, Turkey

\begin{tabular}{|c|c|}
\hline A B S TRACT & ARTICLE INFO \\
\hline $\begin{array}{l}\text { To protect against risks arising from fluctuations in spot prices } \\
\text { and better manage risk, investors might evaluate futures } \\
\text { markets. The role of price discovery in the futures markets and } \\
\text { the possibility of reducing certain risks increase the importance } \\
\text { of researching the relationship between spot and futures prices. } \\
\text { This study aims to determine whether there is a relationship } \\
\text { between the Bitcoin spot prices and the Bitcoin futures prices. } \\
\text { To this end, the relationship between the two markets is } \\
\text { analyzed using Johansen Cointegration analysis and Vector } \\
\text { Error Correction Model (VECM) using the daily data of the } \\
\text { period } 02.23 .2017 \text { - 08.31.2021. Unit root tests show that each } \\
\text { series are not stationary at the level values and that the first } \\
\text { differences of the series are stationary. The results of the } \\
\text { cointegration analysis show that there is a long-term } \\
\text { equilibrium relationship between the bitcoin spot market and } \\
\text { the bitcoin futures market, and it is a single cointegration } \\
\text { vector. The Granger causality test based on the vector error } \\
\text { correction model was used to determine the causality } \\
\text { relationship between the series. It has been determined that } \\
\text { there is a unidirectional causality relationship from the Bitcoin } \\
\text { spot market to the Bitcoin futures market. Bitcoin is a new } \\
\text { financial tool that attracts the attention of investors. Investors } \\
\text { make transactions on Bitcoin for speculative purposes. } \\
\text { Therefore, unlike other investment instruments, spot prices in } \\
\text { the bitcoin market affect futures prices. }\end{array}$ & $\begin{array}{l}\text { Keywords: } \\
\text { Bitcoin Spot Market, Bitcoin Futures } \\
\text { Market, Cointegration, Vector Error } \\
\text { Correction Model (VECM) } \\
\text { *Corresponding author: } \\
\text { letifeozdemir@aku.edu.tr } \\
\text { (Letife Özdemir) } \\
\text { Article history: } \\
\text { Received :14.10.2021 } \\
\text { Revised :27.11.2021 } \\
\text { Accepted :30.11.2021 } \\
\text { DoI: } \\
\text { https://doi.org/10.51410/jcgirm.8.2.11 }\end{array}$ \\
\hline
\end{tabular}

\section{INTRODUCTION}

Cryptocurrency is a virtual money system traded in a digital and technology-based financial system. It is money issued digitally by individuals or institutions rather than states. Cryptocurrencies are used for investment purposes rather than commercial transactions. Bitcoin is the first digital currency. Although thousands of cryptocurrencies were subsequently mined, bitcoin still has the largest trading volume. Since Bitcoin is bought and sold on private exchanges, its returns are usually high, which causes Bitcoin to become an investment asset (Bouri et al., 2020). 
Bitcoin has also become a new financial asset that portfolio managers consider in their short and longterm investment decisions. So, estimating the price is an important issue that should be emphasized. At the same time, investors need to manage the risks arising from fluctuations in bitcoin prices.

Investors evaluate futures markets to protect themselves from the risks that arise from fluctuations in spot prices and to manage the risk better. The other primary function of futures markets is future price determination. The prices formed in the futures markets indicate the future and are effective in making investors' investment decisions. By this function, futures markets are always in contact with spot markets. Although futures is one of the tools used primarily for hedging purposes, it can be said that it is also used for speculation and arbitrage purposes.

Bitcoin gained significant recognition in a short period of time and reached a significant investor base worldwide. With Bitcoin becoming the centre of attention of investors, in December 2017, the Chicago Board Options Exchange (CBOE) and Chicago Mercantile Exchange (CME) issued and offered Bitcoin futures contracts. Thus, investors provide risk management by including bitcoin futures contracts in their portfolios.

The price discovery role of futures markets and the possibility to mitigate specific risks increase the importance of investigating the relationship between spot and futures markets. However, most studies analyzing the relationship between markets have dealt with stock, foreign exchange and commodity markets. This study contributes to the literature by examining the relationship between bitcoin spot and futures markets. The study, using daily data for the period 02.23.2017 - 08.31.2021, tried to determine whether there is a long-term relationship between the two markets with the Johansen cointegration test. In addition, the Vector Error Correction Model (VECM) was used to investigate whether there is a causal relationship between the markets.

The remainder of the study is organized as follows: Existing literature investigating the relationship between markets is summarized in the second section. The third section introduces the econometric methodology, and the fourth section introduces data. In the fifth section, the relationship between the markets is analyzed econometrically. Finally, the study is completed with the conclusion, where the empirical analysis results are evaluated.

\section{LITERATURE REVIEW}

The price discovery role of the futures market and its ability to mitigate certain risks has increased the importance of examining the relationship between futures markets and spot prices. Therefore, there is substantial research examining the relationship between futures and spot prices. There are many studies in the literature investigating the relationships between spot prices related to futures contracts based on stocks, foreign exchange and commodities (Pok and Poshakwale, 2004; Ryoo and Smith, 2004; Srinivasan, 2009; Lafuente-Luengo, 2009; Tse and Chan, 2010; Jerry Ho et al. 2010; Ersoy and Bayrakdaroğlu, 2013; İşeri and Kaçmazer, 2016; Kirkulak-Uludağ and Lkhamazhapov, 2016; Ruan et 
al. 2016). However, studies examining the relationship between Bitcoin spot and futures market are limited.

Hu et al. (2019) examined causality relationships, cointegration and price discovery between Bitcoin's spot and futures markets using daily data. As a result of the Granger causality test, they concluded that there is a bidirectional causality relationship between the spot price and the CME futures prices. In addition, a cointegration relationship between spot and futures markets has been determined. In the price discovery process, it has been seen that futures prices dominate, implying a leading informative role. Shynkevich (2019) suggests that the introduction of bitcoin futures has increased the informational efficiency of the bitcoin spot market.

Kapar and Olmo (2019) analyzed the Bitcoin price discovery process. Using data from December 2017 to May 2018, they compute Hasbrouck's information share and Gonzalo and Granger's common factor component to quantify the contribution of each market to the price discovery process. Both methods coincide with suggesting that the Bitcoin futures market dominates the price discovery process. Likewise, Fassas et al. (2020) examine the contribution of bitcoin futures contracts to the bitcoin price discovery process. They find evidence that although the volume of bitcoin traded on the spot market exceeds the volume of the futures market, the futures market plays a more critical role in incorporating new information about the value of bitcoin. The empirical research also provides evidence of strong bidirectional dependence in the intraday volatility of the spot and futures markets.

Wu et al. (2021) use the fractional cointegrating vector autoregressive (FCVAR) model to examine high-frequency price discovery of bitcoin spot and futures prices from 18 December 2017 to 31 July 2020. The results show that the bitcoin futures market dominates the price discovery process. In addition, it has been determined that bitcoin price discovery leadership has moved to the spot market during the Covid-19 pandemic.

Baur and Dimpfle (2019) examine the contribution of the 2017 launch of bitcoin futures by the CBOE and CME to price discovery. As a result of the analysis, it has been determined that the Bitcoin spot price drives the futures price. This result has been attributed to the higher trading volume and longer trading hours of the globally distributed bitcoin spot market, compared to the relatively limited access to US-based futures markets.

Jalan et al. (2021) indicate that the introduction of bitcoin futures potentially exerted a downward impact on the USD bitcoin spot market return and skewness and an upward one on volatility, kurtosis and liquidity, which became higher after futures were introduced.

\section{METHODOLOGY}

To measure the causality relationship between the Bitcoin spot market and the futures market, the Johansen cointegration test is used to determine whether there is a long-term relationship between the markets. Then, the causality relationship between the markets was investigated with the Vector Error Correction Model.

PAGE 160| Journal of Corporate Governance, Insurance, and Risk Management | 2021, VOL. 8, Series. 2 


\subsection{Cointegration Test}

Cointegration means that the variables move together in the long run. If all variables are stationary at the same level, cointegration methods test whether there is a long-term relationship between the series. The existence of a long-term equilibrium relationship between variables was investigated according to the cointegration method developed by Johansen (1988) and Johansen and Juselius (1990). The Johansen cointegration test is based on the vector autoregression model (VAR) analysis. The VAR model is shown as follows (Brooks, 2008);

$$
\begin{aligned}
& \mathrm{y}_{\mathrm{t}}=\beta_{1} \mathrm{y}_{\mathrm{t}-1}+\beta_{2} \mathrm{y}_{\mathrm{t}-2}+\cdots+\beta_{\mathrm{k}} \mathrm{y}_{\mathrm{t}-\mathrm{k}}+\mathrm{u}_{\mathrm{t}} \\
& \Delta y_{t}=\Pi y_{t-k}+\Gamma_{1} \Delta y_{t-1}+\Gamma_{2} \Delta y_{t-2}+\cdots+\Gamma_{k-1} \Delta y_{t-(k-1)}+u_{t}
\end{aligned}
$$

where $\Gamma$ and $\Pi$ represent coefficient matrices. Coefficient matrix $\Pi$ contains information about longterm relationships. In Johansen and Juselius's cointegration method, two different test statistics, trace test statistics and maximum eigenvalue test statistics, have been developed to reveal the existence of the cointegration relationship and the number of a cointegrated vector. These test statistics are as follows;

$$
\begin{aligned}
& \lambda_{\text {trace }}(r)=-T \sum_{i=r+1}^{g} \ln \left(1-\hat{\lambda}_{i}\right) \\
& \lambda_{\max }(r, r+1)=-T \ln \left(1-\hat{\lambda}_{r+1}\right)
\end{aligned}
$$

The cointegration vector number is represented by r. Trace test statistics investigate the cointegration relationship as $r$, and maximum eigenvalue test statistics investigate the cointegration relationship as much as $r+1$ (Brooks, 2008).

\subsection{Vector Error Correction Model}

According to Engle and Granger (1987), if there is cointegration between the variables, it is possible to discuss at least a unidirectional causality relationship between the variables. The fact that the variables are stationary in their first difference and their integration degree is I(1), enables the vector error correction model (VECM) to be used for causality analysis. To determine the direction of possible causality in the VAR model, error correction terms (ECT) should be included in the VECM model, where each variable is used as an independent variable. The vector error correction model is shown as follows: (Charemza and Deadman, 1993).

$$
\Delta Y_{t}=\alpha_{1}+\sum_{i=1}^{p} \beta_{1 i} \Delta X_{t-1}+\sum_{i=1}^{p} \gamma_{1 i} \Delta Y_{t-1}+\varphi E C M_{t-1}+u_{1 t}
$$




$$
\Delta X_{t}=\alpha_{2}+\sum_{i=1}^{p} \beta_{2 i} \Delta X_{t-1}+\sum_{i=1}^{p} \gamma_{2 i} \Delta Y_{t-1}+\varphi E C M_{t-1}+u_{2 t}
$$

In the model, the ECM represents the error correction term. Therefore, the coefficient in front of the error correction term is expected to be negative, between zero and minus one, and to be statistically significant. In this case, it is stated that there will be a long-run causality relationship between the variables. At the same time, the negative value and statistical significance of the ECM coefficient show that the short-term deviations between the series disappear in the long term, and the series comes to equilibrium together in the long term.

\section{DATA}

This study aims to determine whether there is a relationship between the Bitcoin spot market and the Bitcoin futures market. The analysis used the Bitcoin/Dollar exchange rate representing the bitcoin spot market and Bitcoin Futures CME data representing the futures market. The study analyzed daily price data for the period 23.02.2017 to 31.08.2021. Since the data available for the Bitcoin futures contract started on 23.02.2017, the data period started from this date. The data of the variables were taken from the investing database (https:/tr.investing.com/crypto/bitcoin, https://tr.investing.com/crypto/bitcoin/bitcoin-futures). Whether there is a relationship between the Bitcoin spot market and the futures market was analyzed with the Eviews 9 package program by taking the logarithm of the daily data of the variables.

\section{ANALYSIS AND FINDINGS}

To determine the relationship between Bitcoin spot and futures price series, it is first necessary to determine whether the series are stationary or not. The ADF (Augmented Dickey-Fuller) unit root test developed by Dickey and Fuller (1979) and PP (Phillips-Perron) unit root test developed by Phillips Perron (1990) were used for stationarity analysis. The unit root test results for the regression models with constant term and trend terms for price series are presented in Table 1.

Table 1. Results for Unit Root Tests

\begin{tabular}{|c|c|c|c|c|}
\hline \multicolumn{2}{|c|}{ Series } & $\begin{array}{l}\text { Augmented Dickey-Fuller } \\
\text { (ADF) Test }\end{array}$ & $\begin{array}{l}\text { Philips-Perron } \\
\text { (PP) Test }\end{array}$ & Stationary \\
\hline \multirow[t]{2}{*}{ Spot } & Level & $-1.906443(0)$ & $-1.954119(8)$ & \multirow[t]{2}{*}{$\mathrm{I}(1)$} \\
\hline & 1 st Diff. & $-38.51649(0)^{* * *}$ & $-38.48215(8)^{* * *}$ & \\
\hline \multirow[t]{2}{*}{ Future } & Level & $-2.327303(1)$ & $-2.407751(5)$ & \multirow[t]{2}{*}{$\mathrm{I}(1)$} \\
\hline & 1 st Diff. & $-40.07898(0)^{* * *}$ & $-40.04926(4)^{* * *}$ & \\
\hline
\end{tabular}

*** indicates $1 \%$ of the significance level. Values in parentheses are based on Schwarz statistical information criteria for ADF; For PP, the kernel method "Barlettkernel" and the bandwidth show the optimal lag length according to the "Newey West Bandwith" method.

Source: Authors’ calculations. 
In the ADF (Augmented Dickey-Fuller) and PP (Philips-Perron) tests, the H0 (basic hypothesis) is established as the series has a unit root, that is, it is not stationary. Since the absolute values of the $t$ values obtained for the ADF test statistic are smaller than the absolute values of the critical values of the $1 \%, 5 \%$ and $10 \%$ significance levels, it is seen that the price series have a unit root, that is, the price series are not stationary at the level values. The Phillips Perron test statistic also gives results that support the ADF test statistic. Therefore, it has been concluded that the price series that are not stationary in level values do not have a unit root in the first difference, that is, their integration degree is $I(1)$.

\subsection{Cointegration Analysis}

The fact that the price series are integrated to the same degree does not mean that they always move together in the long run. After determining that the price series are stationary at the first difference, the existence of a long-term equilibrium relationship between the series was investigated according to the cointegration method developed by Johansen (1988) and Johansen and Juselius (1990). To perform a cointegration test, an unconstrained VAR model should be estimated with the variables used in the model, and the lag number of the model should be determined. The appropriate lag length for cointegration tests was determined with the help of the classical VAR model. Suitable lag lengths for the VAR model are shown in Table 2.

Table 2. Suitable lag lengths for the VAR model

\begin{tabular}{|l|l|l|l|l|l|l|}
\hline Lag & LogL & LR & FPE & AIC & SC & HQ \\
\hline 0 & -1946.461 & NA & 0.062676 & 2.905981 & 2.913739 & 2.908887 \\
\hline 1 & 3856.599 & 11580.15 & $1.10 \mathrm{e}-05$ & -5.742876 & -5.719605 & -5.734158 \\
\hline $\mathbf{2}$ & $\mathbf{3 8 8 9 . 4 1 4}$ & $\mathbf{6 5 . 3 8 6 9 2}$ & $\mathbf{1 . 0 5 e - 0 5 *}$ & $\mathbf{- 5 . 7 8 5 8 5 3}$ & $\mathbf{- 5 . 7 4 7 0 6 7 *}$ & $\mathbf{- 5 . 7 7 1 3 2 3 *}$ \\
\hline 3 & 3893.194 & 7.519260 & $1.05 \mathrm{e}-05$ & -5.785524 & -5.731224 & -5.765182 \\
\hline 4 & 3894.202 & 2.003739 & $1.06 \mathrm{e}-05$ & -5.781062 & -5.711248 & -5.754908 \\
\hline 5 & 3894.532 & 0.653811 & $1.06 \mathrm{e}-05$ & -5.775588 & -5.690260 & -5.743622 \\
\hline 6 & 3898.063 & 6.994557 & $1.06 \mathrm{e}-05$ & -5.774890 & -5.674047 & -5.737111 \\
\hline 7 & 3902.189 & 8.158152 & $1.06 \mathrm{e}-05$ & -5.775076 & -5.658719 & -5.731486 \\
\hline 8 & 3904.992 & 5.535994 & $1.07 \mathrm{e}-05$ & -5.773292 & -5.641420 & -5.723890 \\
\hline
\end{tabular}

Indicates the optimal lag length determined by the criteria. LR: Likelihood Ratio; FPE: Final Prediction error; AIC: Akaike Information criteria; SC: Schwarz Information criteria; HQ: Hannan-Quinn information criterion. Source: Authors' calculations.

The appropriate lag length for the estimated VAR model was determined as two according to the FPE, AIC, SC and HQ information criteria. To determine whether the VAR model estimated for two lag lengths includes the unit root, the inverse roots of the AR characteristic polynomial within the unit circle were examined. It is understood from the following figure that all of the reverse roots of the AR characteristic polynomial are located within the unit circle. Therefore, the inverse roots are located within the unit circle reveal that the estimated model has a stationary structure. 
Inverse Roots of AR Characteristic Polynomial

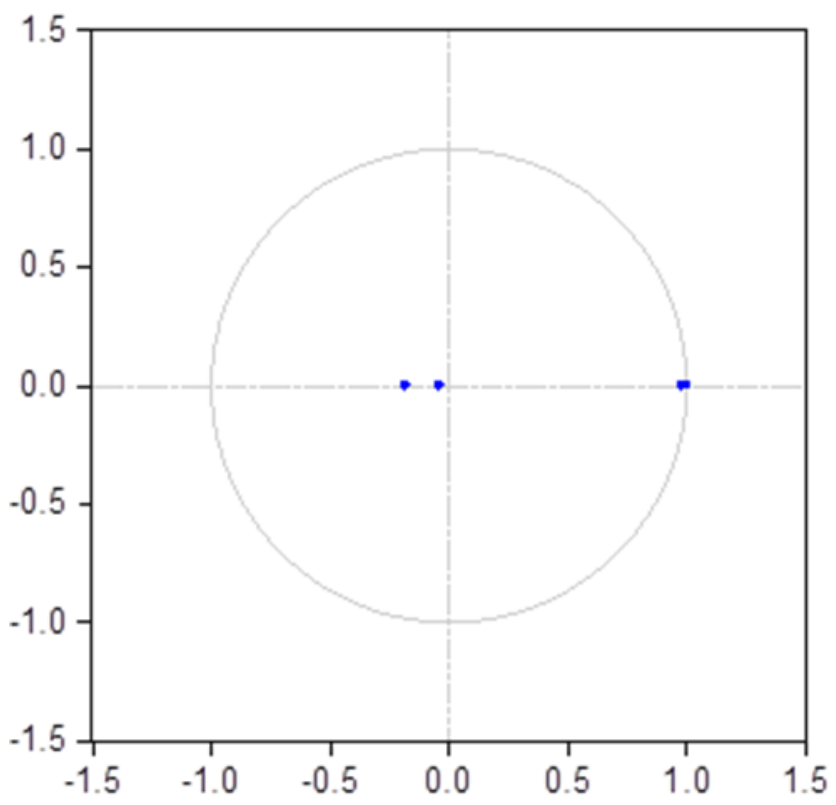

Figure 1. Inverse Roots of AR Characteristic Polynomial of Bitcoin Spot-Futures Model Source: Authors' calculations.

The Johansen cointegration test (Johansen, 1988; Johansen and Juselius, 1990) was used to determine the existence of a long-term relationship between the Bitcoin Spot and Futures Prices. Cointegration test results with the determined lag length are given in Table 3.

Table 3. Results of Johansen Cointegration Test

\begin{tabular}{|l|l|l|c|}
\hline Hypothesis & Trace Statistics & $\mathbf{5 \%}$ Critical Value & Probability** \\
\hline $\mathrm{r}=0^{*}$ & 38.84436 & 25.87211 & 0.0007 \\
\hline $\mathrm{r} \leq 1$ & 6.554089 & 12.51798 & 0.3933 \\
\hline Hypothesis & Max-Eigenvalue Statistics & $\mathbf{5 \%}$ Critical Value & Probability** \\
\hline $\mathrm{r}=0^{*}$ & 32.29027 & 19.38704 & 0.0004 \\
\hline $\mathrm{r} \leq 1$ & 6.554089 & 12.51798 & 0.3933 \\
\hline
\end{tabular}

Existence of one cointegrating vector at 5\% significance level.

*Indicates the rejection of the null hypothesis at 5\% significance level.

**Indicates MacKinnon, Haug, and Michelis (1999) p-values.

Source: Authors’ calculations.

According to the maximum eigenvalue and trace statistics obtained as a result of the Johansen cointegration test, the null hypothesis is rejected, that is, the hypothesis that predicts at least one cointegration vector is accepted at the level of 5\% significance. During the analysis period, these results indicate a long-term equilibrium relationship between Bitcoin Spot and Futures prices.

\subsection{Vector Error Correction Model}

Although cointegration analysis shows a long-term relationship between the variables, it does not provide any information about the direction of Granger causality. Therefore, the causality relationship 
and the direction of the relationship between Bitcoin spot and futures price series were investigated with the Vector Error Correction Model (VECM) proposed by Engle and Granger (1987). According to the VECM model, it is possible to model the changes in the dependent variable as a lagged function of the changes in the explanatory variables and the error correction coefficient as follows.

$\Delta$ Spot $_{t}=\alpha_{1}+\sum_{i=1}^{p} \beta_{1 i} \Delta$ Spot $_{t-i}+\sum_{i=1}^{p} \gamma_{1 i} \Delta$ Futures $_{t-i}+\psi_{1}$ ECM $_{t-1}+\varepsilon_{1 t}$

$\Delta$ Futures $_{t}=\alpha_{2}+\sum_{i=1}^{p} \beta_{2 i} \Delta$ Futures $_{t-i}+\sum_{i=1}^{p} \gamma_{2 i} \Delta$ Spot $_{t-i}+\psi_{2}$ ECM $_{t-1}+\varepsilon_{2 t}$

There is an assumption of long-term equilibrium between the variables, and there will be deviations from this long-run equilibrium in the short run. How long it will take for these deviations to disappear in the long term is determined by the Vector Error Correction Model. ECM represents the error correction term in the Error Correction model. The coefficient of the error correction term being between zero and minus one and being statistically significant indicates a long-term causality relationship between the variables. The Vector error correction model results are given in Table 4 .

Table 4. Vector Error Correction Model (VECM)

\begin{tabular}{|l|c|c|}
\hline & D(SPOT) & D(FUTURES) \\
\hline \multirow{3}{*}{ CointEq1 } & -0.019704 & -0.041233 \\
\cline { 2 - 3 } & $0.00496)$ & $(0.00773)$ \\
\cline { 2 - 3 } & {$[-3.97627]$} & {$[-5.33743]$} \\
\hline
\end{tabular}

Source: Authors' calculations.

While Bitcoin spot prices are the dependent variable, the error correction coefficient is negative and statistically significant. This shows that there is a long-run causality relationship between Bitcoin spot and futures prices. The error correction coefficient was found to be 0.019704 . Accordingly, approximately 0.019704 of the deviations that occur in a short time in the Bitcoin spot market disappear every day. That is, these deviations will reach long-term equilibrium again in about 51 days $(1 / \mathrm{ECM}=1 / 0.019704)$. While Bitcoin futures prices are the dependent variable, the error correction coefficient is negative and statistically significant. This shows that there is a long-run causality relationship between Bitcoin spot and futures prices. According to the error correction coefficient, approximately 0.041233 of the deviations that occur in a short time in the Bitcoin futures market disappear every day. That is, these deviations will reach the long-term equilibrium again in about 24 days $(1 / \mathrm{ECM}=1 / 0.041233)$. 
The Granger causality test based on the Vector error correction model was applied to investigate the direction of causality relationship between Bitcoin spot and futures market. The causality test results are presented in Table 5.

Table 5. Results of VECM Granger Causality Test

\begin{tabular}{|l|l|l|l|}
\hline Hypothesis & Chi-Square & Probability & $\begin{array}{l}\text { Direction of } \\
\text { Causality }\end{array}$ \\
\hline $\begin{array}{l}\text { The Bitcoin Spot market is not the Granger cause } \\
\text { of the Bitcoin Futures Market. }\end{array}$ & 32.97852 & 0.0000 & \multirow{2}{*}{$\mathrm{S}$} \\
\cline { 1 - 2 } $\begin{array}{l}\text { The Bitcoin Futures Market is not the Granger } \\
\text { cause of the Bitcoin Spot Market. }\end{array}$ & 2.625817 & 0.2690 & \\
\hline
\end{tabular}

Source: Authors' calculations.

When Table 5 is examined, the null hypothesis that the Bitcoin spot market does not have Granger causality over the Bitcoin futures market is rejected. However, the null hypothesis that the bitcoin futures market has no Granger causality over the bitcoin spot market is accepted. Granger causality test results show a unidirectional causality relationship from the bitcoin spot market to the futures market.

\section{CONCLUSION}

While the popularity and value of Bitcoin are increasing day by day in the world, the number of studies on future price prediction is also increasing. Identifying the relationship between the bitcoin spot market and the bitcoin futures market is essential for bitcoin investors and portfolio managers. This study investigated the relationship between the bitcoin spot market and the bitcoin futures market. To examine the relationship between the markets, it is necessary to test whether the price series are stationary. As a result of ADF and PP unit root tests, it could be concluded that bitcoin spot and futures price series are not stationary at level values. When the first difference of the series is taken, it is determined that they are stationary, that is, the degree of integration is I(1). The fact that price series are integrated to the same degree does not mean that they always act together in the long run. The Johansen cointegration test was used to determine the existence of a long-term relationship between bitcoin spot and futures prices, which are equally integrated. As a result of the Johansen cointegration test, it was determined that there was a long-term equilibrium relationship between the markets during the analysis period. This conclusion supports the cointegration test results done by $\mathrm{Hu}$ et al. (2019). Since there is cointegration between the series, the causality test was performed using the VECM model. According to the VECM model, it has been determined that there is a long-term causality relationship between the bitcoin spot and the futures market. The Granger causality test based on the Vector Error Correction Model was used to determine the direction of the causal relationship between the bitcoin spot market and the bitcoin futures market. As a result of the causality test, it was determined that there is a unidirectional causality relationship from the bitcoin spot market to the futures market. The study's findings showing that there is a relationship from the spot market to 
the futures market are in line with the results of the study by Baur and Dimpfle (2019). Bitcoin is a new financial investment tool that attracts investors. There is much interest in Bitcoin for speculative purposes by investors. The fact that the transaction volume of the Bitcoin spot market is higher than the futures market, unlike other investment instruments, the spot prices in the bitcoin market affect the futures prices. Portfolio managers and investors considering investing in Bitcoin can increase their profitability and reduce their risks by considering the interaction between the bitcoin spot and the futures market.

The most significant limitation of this study is that bitcoin futures contracts started to be traded on 23.02.2017. The study can be renewed in the future, and the results can be compared by considering a broader time interval. In addition, if each bitcoin futures contract is analyzed and the relationship between the spot market is examined, time-dependent information can be presented to investors. Future studies could use different econometric models, determining the interaction direction of the spot and futures markets as well as the level of impact.

\section{REFERENCES}

Baur, D.G. \& Dimpfle, T. (2019), “Price discovery in bitcoin spot or futures?”, The Journal of Futures Markets, 39, 803-817. DOI: 10.1002/fut.22004.

Bouri, E., Shahzad, S.J.H., Roubaudd, D., Kristoufeke, L. \& Luceyf, B. (2020), "Bitcoin, Gold, and Commodities as Safe Havens for Stocks: New Insight Through Wavelet Analysis”, The Quarterly Review of Economics and Finance, 77, 156-164. https://doi.org/10.1016/j.qref.2020.03.004.

Brooks, C. (2008), Introductory Econometrics for Finance, Cambridge University Press., Cambridge.

Charemza, W.W. \& Deadman, D.F. (1993), New Directions in Econometric Practice: General to Specific Modelling Cointegration and Vector Autoregression, Edward Elgar Publishing Limited, Cambridge, Aldershot, Hanst

Dickey, D. \& Fuller, W.A. (1979), "Distributions of the Estimators for Autoregressive Time Series with a Unit Root”, The American Statistical Association, 74, 423-431.

Engle, R.F. \& Granger, C.W.J. (1987), “Cointegration and Error Correction: Representation, Estimation and Testing”, Econometrica, 55, 2, 251-276.

Ersoy, E. \& Bayrakdaroğlu, A. (2013). “The Lead-lag Relationship Between ISE 30 Index and the TURKDEX-ISE 30 Index Futures Contracts”, Istanbul University Journal of the School of Business, 42(1), 26-40. 
Fassas, A. P., Papadaöou, S. \& Koulis, A. (2020), "Price Discovery in Bitcoin Futures”, Research in International Business and Finance, 52, 101116. https://doi.org/10.1016/j.ribaf.2019.101116.

Hu, Y., Hou, Y. \& Oxley, L. (2019), “Spot and Futures Prices of Bitcoin: Causality, Cointegration and Price Discovery from a Time-Varying Perspective”, Working Paper in Economics, 13/19, University Of Waikato, Hamilton New Zealand.

İşeri, M. \& Kaçmazer, M. (2016), “Examining Casuality (Lead-Lag) Relationship Between BIST30 Index and BIST30 Equity Index Futures in the Period of 2005-2015”, Finance Political \& Economic Comments, 53(615), 9-21.

Jalan, A., Matkovskyy, R. \& Urquhart, A. (2021), "What Effect Did the Introduction of Bitcoin Futures have on the Bitcoin Spot Market?”, The European Journal of Finance, 27, 13, 12511281. DOI: 10.1080/1351847X.2020.1869992.

Jerry Ho, W., Wang, Y. \& Liou, G. (2010), “The Interactive Relationship Among International Gold Indices, Gold Futures and the Overall Economy”, African Journal of Business Management. 4(9), 1903-1915.

Johansen, J. (1988), “Statistical Analysis of Cointegrating Vectors”, Economic Dynamics and Control, 12, 231-54.

Johansen, S. \& Juselius, K. (1990), "Maximum Likelihood Estimation and Inference on Cointegration with Application to the Demand for Money”, Oxford Bulletin of Economics and Statistics, 52, 169-210.

Kapar, B. \& Olmo, J. (2019), “An Analysis of Price Discovery between Bitcoin Futures and Spot Markets, Economics Letters”, 174, 62-64. https://doi.org/10.1016/j.econlet.2018.10.031.

Kirkulak-Uludağ, B. \& Lkhamazhapov, Z. (2016), “The Volatility Dynamics of Spot and Futures Gold Prices: Evidence from Russia”, Research in International Business and Finance, 38, 474-484, DOI: 10.1016/j.ribaf.2016.07.003.

Lafuente-Luengo, J. A. (2009), “Intraday Realized Volatility Relationships Between the S\&P 500 Spot and Futures Market”, Journal of Derivatives \& Hedge Funds, 15(2), 116-121.

MacKinnon, J.G., Haug, A.A. and Michelis, L. (1999), Numerical Distribution Functions of Likelihood Ratio Tests for Cointegration. Journal of Applied Econometrics, 14, 563-577.

Perron, P. (1990), “Testing for a Unit Root in a Time Series with a Changing Mean”, Journal of Business and Economic Statistics, 8, 153-162.

Pok, W.C. \& Poshakwale, S. (2004), “The Impact of the Introduction of Futures Contracts on the Spot Market Volatility: The Case of Kuala Lumpur Stock Exchange”, Applied Financial Economics, 14, 143-154.

PAGE 168| Journal of Corporate Governance, Insurance, and Risk Management | 2021, VOL. 8, Series. 2 
Ruan, Q., Huang, Y. \& Jiang, W. (2016), “The Exceedance and Cross-Correlations Between the Gold Spot and Futures Markets”, Physica A, 463,139-151, DOI: 10.1016/j.physa.2016.07.021

Ryoo, H.J. \& Smith, G. (2004), “The Impact of Stock Index Futures on the Korean Stock Market”, Applied Financial Economics, 14, 243-251.

Shynkevich, A. (2019), "Impact of Bitcoin Futures on the Informational Efficiency of Bitcoin Spot Market”, The Journal of Futures Markets, 41, 115-134. DOI:10.1002/fut.22164.

Srinivasan, P. (2009), "An Empirical Analysis of Price Discovery in the NSE Spot and Futures Markets of India”, IUP Journal of Applied Finance, 15(11), 24-36.

Tse, Y.K. \& Chan, W.S. (2010). “The Lead-Lag Relation Between the S\&P 500 Spot and Futures Markets: An Intraday-Data Analysis Using a Threshold Regression Model”, The Japanese Economic Review, 61(1), 133-144.

Wu, J., Xu, K., Zheng, X. \& Chen, J. (2021), "Fractional Cointegration in Bitcoin Spot and Futures Markets”, The Journal of Futures Markets, 41, 9, 1478-1494. DOI:10.1002/fut.22216.

Acknowledgement: This study was presented in summary at the 13th International Conference Competitiveness and Stability in the Knowledge-Based Economy held on 30 October 2021 in Craiova, Romania. 